\title{
The Effect of Integrated Nutrient Management (INM) and Zn Fertilization on Yield of Potato
}

\author{
Ajay Dev ${ }^{1}$, Suresh Kumar ${ }^{1}$, Deepak Kumar ${ }^{2}$, Vivek Kumar Patel ${ }^{1}{ }^{*}$, Abhay Kumar ${ }^{3}$, \\ Rohit Kumar Sahu ${ }^{4}$ and Pratibha Singh $^{5}$
}

${ }^{1}$ Department of Soil Science and Agricultural Chemistry, Acharya Narendra Deva University

of Agriculture \& Technology, Kumarganj, Ayodhya, Uttar Pradesh (224229), India

${ }^{2}$ Department of Soil Science, S. V. P. University of Agriculture and Technology Meerut, Uttar Pradesh (250110), India

${ }^{3}$ Department of Agricultural Biotechnology and Molecular Biology, RPCAU, Pusa, Samasatipur, Bihar (848125), India

${ }^{4}$ Department of Genetics and Plant Breeding,

${ }^{5}$ Department of Extension Education, D.D.U, Gorakhpur University, Gorakgpur, Uttar Pradesh- 273009, India

*Corresponding author

\section{Keywords}

ZnSO4, NPK, FYM, Potato, Yield and growth attributes

\section{Article Info}

Accepted:

12 March 2020 Available Online: 10 April 2020

\section{A B S T R A C T}

The present investigation was carried out at Student Instructional farm Narendra Deva University of Agriculture and Technology Narendra Nagar Kumarganj, Ayodhya (U.P.) during Rabi season 2017-2018. To evaluate the Effect of nutrient management practices on the performance of potato (Solanum tuberosum L.) and soil fertility. The five treatments comprised with various levels of $75 \%$ and $100 \%$ recommended doses of $\mathrm{NPK}, \mathrm{ZnSO}_{4}(20,30 \mathrm{and} 40 \mathrm{~kg}$ $\mathrm{ha}^{-1}$ ) and $25 \%$ Nitrogen by Farm yard manure were tested against 100\% NPK fertilizers alone were replicated four time in randomized block design (RBD) potato crop the variety KufriBaadshah was taken a test crop. Results revealed that the integrated use of $75 \%$ recommended doses of NPK fertilizers (180:80:100), 25\% nitrogen by Farm yard manure as well as $20 \mathrm{~kg} \mathrm{ha}^{-1} \mathrm{ZnSO}_{4}$ in potato was found superior for higher plant growth, productivity and better marketable quality of tubers. The availability of NPK nutrients, organic carbon, moisture retention capacity of soil increased while bulk density, soil $\mathrm{pH}$, and electrical conductivity decreased at higher rate by applying $75 \%$ recommended doses of NPK and $20 \mathrm{~kg} \mathrm{ha}^{-1} \mathrm{ZnSO}_{4}$ fertilizers with Farm yard manure as compared to $100 \%$ recommended doses of NPK fertilizers alone. The application of $75 \%$ recommended doses of NPK, $20 \mathrm{~kg} \mathrm{ha}^{-1} \mathrm{ZnSO}_{4}$ fertilizers and 25\% Nitrogen by Farm yard manure provided highest net returns (Rs. 193639) and cast benefit ratio (2.48). It was concluded that application of $75 \% \mathrm{RDF}, 20 \mathrm{~kg} \mathrm{ha}^{-1} \mathrm{ZnSO}_{4}$ fertilizers and $25 \%$ nitrogen by Farm yard manure may be recommended for higher productivity and returns, and build up soil fertility. 


\section{Introduction}

Potato (Solanum tuberosum L.) is herbaceous annual plant and belongs to the family Solanaceae. The edible part of potato is modified underground stem. It is originated in South America and brought to India in $16^{\text {th }}$ century by the Portuguese. Potato is the $4^{\text {th }}$ major food crop after rice, wheat and maize of the world. Potato is rich source of energy and produces more food per unit area and time than all major food crops. Potato is one of the most efficient food crop which produce more dry matter, dietary fiber, quality protein, minerals and vitamin than wheat, maize and rice per unit area and time is considered as a balanced and nutritive food.

Potato can be compared only with rice, wheat and maize for its contribution towards securing the food and nutrition and avoiding poverty and hunger especially in developing countries, where food is perpetually on demand to feed increasing population living with inherent social and political conflict. It is also utilized in preparation of readymade products like fried items (Dices, vanies, flakes, granules, starch, gravy thicker, potato custard etc.) and canned potato. India is the second largest producer of potato contributing $10-11 \%$ of the world potato production after China with the production of 50.33 million tones from an area of 1.843 million ha.

The total area in world under potato cultivation is 193.03 mha and total production is $388.19 \mathrm{~m}$ tones with 20.11 tones productivity (FAOSTAT 2017). Where as in India, total area is $21.24 \mathrm{~m}$ ha and production is $50.30 \mathrm{~m}$ tones with 23.9 tones productivity. The contribution of U.P. alone in area and production is 0.614 million ha and 15.56 million tones with $22.77 /$ ha productivity (NHB, 2017-18), respectively. Nitrogen is the most limiting in potato production and has a great influence on crop growth, tuber yield and quality. A mature crop of potato yielding $25-30$ tonnes tuber/ha consumes $120-140 \mathrm{~kg}$ $\mathrm{N} / \mathrm{ha}$.The Indian soils generally deficient in organic matter and are thus unable to release $\mathrm{N}$ at the desired rate, required to maintain adequate supply to the growing plant. Therefore, application of $\mathrm{N}$ in the form of fertilizer and manures becomes necessary to meet the crop needs.

The deficiency of $\mathrm{N}$ leads to pale-green colouration of leaf margins at the initial stage; turning to pale-yellow foliage in case of acute deficiency. The symptoms first appear at lower leaves. However, excess of $\mathrm{N}$ delays tuber initiation and onset of linear phase of tuber growth, ultimately resulting in lower yield. The economic response of potato in alluvial soils of north-western and central Indo-Gangetic plains in India has been reported upto $180 \mathrm{~kg} \mathrm{~N} / \mathrm{ha}$.

In potato crop, application of $\mathrm{N}$ at proper time is important for getting full benefit of applied $\mathrm{N}$. In general, for plains where growth period is short (100-120 days), application of $\mathrm{N}$ in two split doses, i.e. half at planting and rest at the time of earthing up gives higher yields and results in higher $\mathrm{N}$ recovery than applying entire dose at planting. This reduces leaching and other losses and gives better utilization of applied N. Phosphorus is the most important nutrient for plant.

However, Indian soils test generally low to medium in available phosphorus and not more than 30 per cent of applied phosphate is available to current crop, remaining parts gets converted into relatively unavailable form. Potassium has an important role in control of the plant water status and ionic concentrations inside plant tissues, including stomata. as a result of improved cell strength that potassium provides in potatoes stress such as frost can be tolerated. 
The application of organic manures particularly FYM or compost is recommended for potato crop. Organic manure not only supply nutrients to the crop but also improves physical conditions of soils, such as texture and its water holding capacity. In potatoes, Zinc deficiency symptoms are variable.

In general, the leaves are smaller and the plants are stunted in growth. The leaves fold inwards giving a fern like appearance, grayish brown to bronze colored Blotches appears first on the middle leaves and latest on all leaves. Yield responses to zinc can be expected in crops grown on soils with a low or high $\mathrm{pH}$ if the Zinc levels are low.

Therefore, the Zinc plays an important role in potato production. Zinc maintains active state of auxin and alck of it leads to excessive destruction of auxin due to an increase in oxidation. Zinc is also essential for the function and structure of aldolases, dehydrogenases, phosphatases, aspartate transcarbamylase and isomerase (Auld, 2001).

Protein synthesis is markedly influenced through some action of Zinc and also influenced in photosynthesis by the speedy release of respiratory $\mathrm{CO}_{2}$. Zinc is essential for carbohydrate and phosphorus metabolism and synthesis of RNA and chlorophyll formation (Pandey and Sinha, 2006).

So the Zinc is key factor of potato production. Farm yard manure is organic matter and refers to the well-decomposed mixture of dung, urine, farm litter (bedding material).In FYM found richest nutrients and directly available to the plants.

Though single nutrient source may supply the respective required nutrients for plant but integrated use of all source (Organic and inorganic) is required for balanced plant nutrient (Arora 2008).

\section{Materials and Methods}

A field experiment was conducted during the winter season of 2017-18 at Experiment farm of Narendra Deva University of Agriculture \& Technology, Narendra Nagar (Kumarganj), Ayodhya (Faizabad) (U.P.) India, which is located $42 \mathrm{~km}$ away from Faizabad on Faizabad-Raibarelly road.

Geographically, this experimental site falls under humid, sub-tropical climate and is located at $26.47^{0} \mathrm{~N}$ latitude and $82.12^{\circ} \mathrm{E}$ longitude on an elevation of about 113 meters above mean sea level in the Indo- Gangetic alluvial plain of eastern Uttar Pradesh. Ayodhya region receives a mean annual precipitation of about $1200 \mathrm{~mm}$.

\section{Growth attributes}

Observation on various growth parameters viz., plant height, number of physiological active leaves and leaf area index/plant was made at 30,60 and 90 days after sowing (DAS) and at harvest of the crop.

\section{Emergence percentage}

Plant population of each treatments were counted after 30 days of planting from three randomly selected rows in each plot and figure were converted into per cent to compute emergence percentage.

\section{Number of haulms per hill}

Numbers of haulms per hill were counted at 60 days after planting. For this purpose five plants were selected in each plot at random and they were tagged and then numbers of haulms per hills were counted. The average numbers of haulms were calculated in order to know the average number of haulms per plant. 


\section{Plant height (cm)}

Plant height was measured at 60 days after planting. Plants selected for number of haulm per plant were used for this purpose. Plant heights were measured in centimeter with the help of meter scale. Height was measured from the surface of the ridge to the apex of the plants and then average height of plants were finally calculated and presented.

\section{Yield and quality of tubers}

\section{Gradation of tubers:}

For determining the size of tuber, the produce of each plots was graded and weighted separately. The tubers above $75 \mathrm{~g}$ were counted in A grade, $50-75 \mathrm{~g}$ were placed in B grade, $25-50 \mathrm{~g}$ were kept in $\mathrm{C}$ grade respectively.

\section{Weight of $\mathrm{A}, \mathrm{B}$, and $\mathrm{C}$ grade tubers per plot}

Each plot was harvested separately and tubers weight of $\mathrm{A}, \mathrm{B}$, and $\mathrm{C}$ grade recorded in $\mathrm{kg}$ per plot.

\section{Tuber yield (q/ha)}

After harvesting, the yield of total tubers per plot were recorded in Kilograms separately and converted in to $\mathrm{q} / \mathrm{ha}$.

\section{Specific gravity}

For determining specific gravity the five tubers were selected at random from each plot. Tubers were weighed separately and then they were placed into measuring cylinder containing water. Thus, water which was replaced by the tubers was measured and specific gravity was calculated adopting the formula:
Specific gravity $=\frac{\text { Weightof tuber }(\mathrm{g})}{\text { Volume of water replaced by thetuber }(\mathrm{m} / \mathrm{cc})} \mathrm{X} 100$

\section{Results and Discussion}

\section{Growth parameter}

The plant emergence was found statistically at par with the application of $100 \%$ RDF and 75\%RDF+ 25\% FYM-N the plant growth parameters viz., plant height and number of haulms hill $^{-1}$ were influenced significantly due to application of RDF $75 \%+25 \%$ FYM$\mathrm{N}$ along with the successive increment doses of $\mathrm{ZnSO}_{4}$ viz., 20, 30 and $40 \mathrm{kgha}^{-1}$. This might be due to application of fertilizers in combination with organic manure which increased the nutrient-use efficiency through modification of soil physical condition, and resulted in higher total uptake of nutrients because of better root penetration leading to better absorption of nutrients and moisture (Yadav et al., 2013a; Kushwah et al., 2005). This increase in growth parameters might be due to increase in uptake of nitrogen, phosphorus and potassium. The growth parameters such as number of leaves and leaf area have the direct association with photosynthetic efficiency of a crop and this might be the reason for higher plant height, halums hill $^{-1}$ of a potato crop. Similar results were also corroborated with the findings of Pandey et al., (2008), Thakare et al., (2007) (Table 1-3).

\section{Effect of nutrient management on tuber grades and tuber yield}

The application of farm yard manure along inorganic fertilizers and $\mathrm{ZnSO}_{4}$ increased the tuber grades. The treatments receiving farm yard manure and inorganic fertilizers (N P K) along with $\mathrm{ZnSO}_{4}$ increased the size of tubers (A grade- $12.13 \mathrm{~kg} \mathrm{plot}^{-1}$ to $12.65 \mathrm{~kg} \mathrm{plot}^{-1}$, B grade- $19.48 \mathrm{~kg} \mathrm{plot}^{-1}$ to $20.26 \mathrm{~kg} \mathrm{plot}^{-1}$ and $\mathrm{C}$ grade- $17.26 \mathrm{~kg} \mathrm{plot}^{-1}$ to $18.20 \mathrm{~kg} \mathrm{plot}^{-1}$ ) 
which was significantly as compared to $100 \%$ recommended doses of NPK fertilizers alone. The lowest quantity of $\mathrm{A}, \mathrm{B}$ and $\mathrm{C}$ grade tubers were recorded in treatment $100 \%$ recommended dose of fertilizers (NPK) and $75 \%$ RDF $+25 \%$ FYM-N. The overall grade wise tubers yield data showed that application of farm yard manure and inorganic fertilizers along with $\mathrm{ZnSO}_{4}$ ) significantly increased the quantity of large size $(>50 \mathrm{~g})$ marketable tubers as compared to treatment $\mathrm{T}_{1} \quad 100 \%$ recommended dose of fertilizers (NPK) alone.

The increasing levels of $\mathrm{ZnSO}_{4}(20,30$ and $40 \mathrm{~kg} / \mathrm{ha}$ ) increased the quantity of large size of tubers but it was statistically at par. On the other side application of $100 \%$ recommended doses of NPK fertilizers alone and $75 \%$ recommended doses of NPK fertilizers and $25 \%$ FYM-N recorded lower quantity of small size tubers ( $>25 \mathrm{~g}$ ) as compared to $75 \%$ recommended doses of fertilizers (NPK) and $25 \%$ farm yard manure along with $\mathrm{ZnSO}_{4}(20$, 30 and $40 \mathrm{~kg} / \mathrm{ha}$ ) treatments respectively (Raghav et al., 2009). Similar observations have also been noted by Singh et al., (2008) and Islam et al., (2013). Thind et al., (2007) also observed that the percent contribution of larger size tubers towards yield was more in
FYM plots than other organic manures. The pooled yield data showed that application of $75 \%$ recommended doses of fertilizers (NPK) and $25 \%$ FYM-N along with successive increment doses of $\mathrm{ZnSO}_{4} \quad(20,30$ and $40 \mathrm{~kg} / \mathrm{ha}$ ) fertilizers increased the tuber yield significantly as compared to $100 \%$ recommended doses of fertilizers (NPK) alone.

Das et al., (2009) reported that the integrated nutrient management by application of both inorganic fertilizers and organic manures increase the different grades tuber production. The increasing level of $75 \%$ recommended doses of fertilizers (NPK) and farm yard manure (9 t/ha) along with $\mathrm{ZnSO}_{4}(20,30$ and $40 \mathrm{~kg} / \mathrm{ha}$ ) fertilizers increased the tuber yield significantly.

This might be due to the increase in photosynthetic activity by zinc application which improves the vegetative growth of potato plant leading to increase in total tuber yield. Similar results were also supported with the finding of Joshi and Raghav (2007), Tiwari and Dwivedi (1991) and Sahota (1985) (Table 4-6).

Table.1 Effect of integrated nutrient management on plant emergence at 30 days after planting

\begin{tabular}{|c|c|}
\hline Treatment & $\begin{array}{l}\text { Emergence Percentage } \\
\text { at } 30 \text { DAP }\end{array}$ \\
\hline$T_{1}$ RDF $100 \%$ & 91.50 \\
\hline $\mathrm{T}_{2}$ RDF $75 \%+25 \%$ FYM-N & 93.20 \\
\hline $\mathrm{T}_{3} \mathrm{RDF} 75 \%+25 \%$ FYM-N+ $\mathrm{ZnSO}_{4} @ 20 \mathrm{kgha}^{-1}$ & 92.70 \\
\hline $\mathrm{T}_{4} \mathrm{RDF} 75 \%+25 \%$ FYM-N+ $\mathrm{ZnSO}_{4} @ 30 \mathrm{kgha}^{-1}$ & 93.00 \\
\hline $\mathrm{T}_{5} \mathrm{RDF} 75 \%+25 \%$ FYM-N+ $\mathrm{ZnSO}_{4} @ 40 \mathrm{kgha}^{-1}$ & 94.20 \\
\hline SEm \pm & 2.61 \\
\hline CD at $5 \%$ & NS \\
\hline
\end{tabular}


Table.2 Effect of nutrient management on number of haulms hill ${ }^{-1}$ at 60 days after planting

\begin{tabular}{|l|c|}
\hline Treatment & $\begin{array}{c}\text { Number of haulms } \\
\text { hill }^{-1} \text { at 60 DAP }\end{array}$ \\
\hline $\mathbf{T}_{\mathbf{1}}$ RDF 100\% & 5.20 \\
\hline $\mathbf{T}_{\mathbf{2}}$ RDF 75\% + 25\% FYM-N & 5.40 \\
\hline $\mathbf{T}_{\mathbf{3}}$ RDF 75\% + 25\% FYM-N+ZnSO $@$ 20kgha $^{-1}$ & 5.80 \\
\hline $\mathbf{T}_{\mathbf{4}}$ RDF 75\% + 25\% FYM-N+ZnSO $@$ 30kgha $^{-1}$ & 6.00 \\
\hline $\mathbf{T}_{\mathbf{5}}$ RDF 75\% + 25\% FYM-N+ZnSO $@$ 40kgha $^{-1}$ & 6.10 \\
\hline SEm \pm & 0.16 \\
\hline CD at 5\% & 0.50 \\
\hline
\end{tabular}

Table.3 Effect of nutrient management on plant height at 60 days after planting

\begin{tabular}{|c|c|}
\hline Treatment & $\begin{array}{c}\text { Plant height }(\mathrm{cm}) \\
\text { at60 DAP }\end{array}$ \\
\hline $\mathrm{T}_{1}$ RDF $100 \%$ & 50.20 \\
\hline$T_{2}$ RDF $75 \%+25 \%$ FYM-N & 51.50 \\
\hline $\mathrm{T}_{3}$ RDF 75\% + 25\% FYM-N+ZnSO ${ }_{4} @ 20 \mathrm{kgha}^{-1}$ & 57.60 \\
\hline $\mathrm{T}_{4}$ RDF 75\% + 25\% FYM-N+ZnSO ${ }_{4} @ 30 \mathrm{kgha}^{-1}$ & 58.90 \\
\hline $\mathrm{T}_{5}$ RDF $75 \%$ + 25\% FYM-N+ZnSO $\mathrm{Z}_{4}$ 40kgha ${ }^{-1}$ & 59.00 \\
\hline SEm \pm & 1.57 \\
\hline CD at $5 \%$ & 4.83 \\
\hline
\end{tabular}

Table.4 Effect of nutrient management on gradation of potato crop

\begin{tabular}{|c|c|c|c|}
\hline \multirow[b]{2}{*}{ Treatment } & C-grade & B-grade & A-grade \\
\hline & $\begin{array}{l}\text { (25-50g)Yield } \\
\left(\mathrm{kg} \mathrm{plot}^{-1}\right)\end{array}$ & $\begin{array}{c}(51-75 \text { g) } \\
\text { Yield } \\
\left(\text { kg plot }^{-1}\right)\end{array}$ & $\begin{array}{c}(>75 \mathrm{~g}) \\
\text { Yield } \\
\left(\mathrm{kg} \mathrm{plot}^{-1}\right)\end{array}$ \\
\hline $\mathrm{T}_{1}$ RDF $100 \%$ & 15.83 & 18.09 & 11.34 \\
\hline $\mathrm{T}_{2}$ RDF $75 \%+25 \%$ FYM-N & 16.06 & 18.68 & 11.73 \\
\hline $\begin{array}{l}\mathrm{T}_{3} \mathrm{RDF} 75 \% \\
\text { 20kgha }^{-1}\end{array}$ & 17.26 & 19.48 & 12.13 \\
\hline 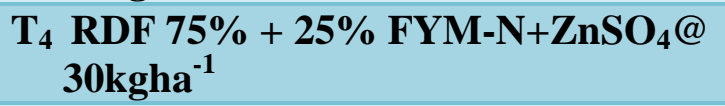 & 17.86 & 19.98 & 12.49 \\
\hline $\mathrm{T}_{5} \mathrm{RDF} \mathrm{75 \%}_{40 \mathrm{kgha}^{-1}}+25 \%$ FYM-N+ZnSO $\mathrm{F}_{4} @$ & 18.20 & 20.26 & 12.65 \\
\hline SEm \pm & 0.47 & 0.43 & 0.26 \\
\hline CD at $5 \%$ & 1.47 & 1.30 & 0.82 \\
\hline
\end{tabular}


Table.5 Effect of nutrients management on total yield of potato ( $\mathrm{qha}^{-1}$ )

\begin{tabular}{|c|c|}
\hline Treatment & $\begin{array}{l}\text { Tuber Yield } \\
\qquad\left(\text { qha }^{-1}\right)\end{array}$ \\
\hline $\mathrm{T}_{1} \mathrm{RDF} \mathbf{1 0 0 \%}$ & 251.39 \\
\hline$T_{2}$ RDF $75 \%+25 \%$ FYM-N & 258.17 \\
\hline $\mathrm{T}_{3}$ RDF 75\% + 25\% FYM-N+ZnSO $@ 20 \mathrm{kgha}^{-1}$ & 271.50 \\
\hline $\mathrm{T}_{4}$ RDF 75\% + 25\% FYM-N+ZnSO F $_{4} 30 \mathrm{kgha}^{-1}$ & 279.64 \\
\hline $\mathrm{T}_{5}$ RDF 75\% + 25\% FYM-N+ZnSO F $_{4} 40 \mathrm{kgha}^{-1}$ & 283.97 \\
\hline SEm \pm & 7.58 \\
\hline CD at $5 \%$ & 23.61 \\
\hline
\end{tabular}

Table.6 Effect of nutrient management on specific gravity of potato

\begin{tabular}{|c|c|}
\hline Treatment & $\begin{array}{l}\text { Specific gravity } \\
\quad\left(\mathrm{g} / \mathrm{cm}^{3}\right)\end{array}$ \\
\hline T RDF $100 \%$ & 1.009 \\
\hline $\mathrm{T}_{2} \mathrm{RDF} 75 \%+25 \%$ FYM-N & 1.016 \\
\hline $\mathrm{T}_{3} \mathrm{RDF} 75 \%+25 \%$ FYM-N+ZnSO $@ 20 \mathrm{kgha}^{-1}$ & 1.018 \\
\hline $\mathrm{T}_{4} \mathrm{RDF} 75 \%+25 \%$ FYM-N+ZnSO @ 30kgha ${ }_{4}^{-1}$ & 1.019 \\
\hline $\mathrm{T}_{5} \mathrm{RDF} 75 \%$ + 25\% FYM-N+ZnSO @ 40kgha & 1.020 \\
\hline SEm. \pm & 0.004 \\
\hline CD at $5 \%$ & NS \\
\hline
\end{tabular}

Effect of nutrient management on specific gravity of potato

Specific gravity of tubers increased by applying $75 \%$ recommended dose of $\mathrm{N} \mathrm{P} \mathrm{K}$ fertilizers with $25 \%$ nitrogen by farm yard manure along with successive increment doses of $\mathrm{ZnSO}_{4}\left(20,30\right.$ and $\left.40 \mathrm{~kg} \mathrm{ha}^{-1}\right)$ fertilizer compared to $100 \%$ recommended dose of NPK fertilizers respectively.

However, no significant variations were observed among the various nutrient management treatment. These results may be supported with the findings of Baishya et al., (2011) and Mandal et al., (1986).

\section{References}

Arora. (2008). Balance nutritional for sustainable crop production. Krishi world, 1-5.

Auld, D. S. (2001). Zinc coordination sphere in biochemical zinc sites. Biometals.14: 271-313.

Baishya, L. K., Ghosh, D. C. and Gupta, V. K. (2011) Yield and quality of potato tubers as influenced by nutrient sources under rain fed condition of Meghalaya. Indian J. Agron. 56 (3): 260-266.

Das PP, Sarkar A and Zamen A (2009). Response of organic and inorganic sources of nutrients on growth and yield of potato in Gangetic alluvial plains of 
west Bengal. In Proceedings of $96^{\text {th }}$ Indian Science Congress, part-II (Abstract), 3-7 th $^{\text {jan.at }}$ NEHU, Shillong, Meghalaya.

FAOSTAT (2017). State Departments of Horticuluure \& Agriculture.

Islam, M. M.; Majid, S. A.; Jannatual, N. M. and FerdousAlam, M. S. (2013). Integrated nutrient management for potato (Solanum tuberosum L.) in grey terrace soil (Aric Albaquipt). Australian Journal of Crop Science; 7(9): 12351241.

Joshi, N. and Raghav, M. (2007). Growth and yield of potato as affected by zinc sulphate and their method of application. Progressive Horticulture. 39: 189-193.

Kushwah, V.S., Singh, S.P. and Lal, S.S. 2005. Effect of manures and Fertilizers on potato (Solanum tuberosum) production. Potato Journal 32(3-4): $157-58$.

Mandal, S. S. and Mazumdar, B. (1986). Response of fertilizer in presence of farm yard manure on the yield of potato. Indian J. Agron., 31: 300-301.

Pandey, S. K. and Sarkar, K. C. (2008). Nutrient management in potato based Cropping System. Indian Journal of fertilizer, 3(9):91-98 \& 101-107.

Pandey, S.N. and Sinha, B.K. (2006). Plant Physiology. Vikas Publishing House $(P)$ Ltd. New Delhi-110014. pp. 132-133.

Sahota, T. S. (1985). Phosphorus and zinc interaction in potato at Shillong. $J$. Indian Potato Asso.12(1-2): 95-97.

Singh AK, Elvitigala T, BhattacharyyaPakrasi M, Aurora R, Ghosh B, Pakrasi HB (2008) Integration of carbon and nitrogen metabolism with energy production is crucial to light acclimation in the cyanobacterium Synechocystis. Plant Physiol 148: 467478

Thakare, R. G.; Jadhao, B. J., Nandre, D. R., Ghawadw, S. M. and Khewate, A. P. (2007). Effect of zinc and iron levels on growth and yield of potato. PlantArchives, 7(1): 275-276.

Thind, S.S., Sidhu, A. S., Sekhon, N. K. and Hira, G. S. (2007) Integrated nutrient management for sustainable crop production in potato. J. Sustainable Agriculture, 29(4): 173-188.

Tiwari, K. N. and Dwivedi, B. S. (1991). Effect of native and fertilizer $\mathrm{Zn}$ on the tuber and $\mathrm{Zn}$ uptake by potato in UdicUstocherpts of Uttar Pradesh. Journal of the Indian Society of Soil Science 39, 396-398.

Yadav, S.K., Singh, Yogeshwar, Kumar, R.P., Yadav, M.K. and Singh, Kalyan. (2013). Effect of organic nitrogen sources on yield, quality and nutrient uptake of rice (Oryza sativa) under different cropping system. VegetosAn International Journal of Plant Research 26(1): 58-66.

\section{How to cite this article:}

Ajay Dev, Suresh Kumar, Deepak Kumar, Vivek Kumar Patel, Abhay Kumar, Rohit Kumar Sahu and Pratibha Singh. 2020. The Effect of Integrated Nutrient Management (INM) and Zn Fertilization on Yield of Potato. Int.J.Curr.Microbiol.App.Sci. 9(04): 1518-1526. doi: https://doi.org/10.20546/ijcmas.2020.904.179 